\title{
Discerning Trends, Contours, and Boundaries in Comparative Education: A Survey of Comparativists and Their Literature
}

\author{
Steven J. Hite \\ steve_hite@byu.edu \\ Bradley J. Cook \\ Erwin H. Epstein
}

Follow this and additional works at: https://scholarsarchive.byu.edu/facpub

Part of the Educational Leadership Commons

\section{Original Publication Citation}

Cook, B.R., Hite, S.J., \& Epstein, E. (24). Discerning trends, contours and boundaries in Comparative Education: A survey of comparativists and their literature. Comparative Education Review, 48(2), 123-149. http://www.jstor.org/stable/1.186/cer.24.48.issue-2

\section{BYU ScholarsArchive Citation}

Hite, Steven J.; Cook, Bradley J.; and Epstein, Erwin H., "Discerning Trends, Contours, and Boundaries in Comparative Education: A Survey of Comparativists and Their Literature" (2004). Faculty Publications. 1040.

https://scholarsarchive.byu.edu/facpub/1040

This Peer-Reviewed Article is brought to you for free and open access by BYU ScholarsArchive. It has been accepted for inclusion in Faculty Publications by an authorized administrator of BYU ScholarsArchive. For more information, please contact ellen_amatangelo@byu.edu. 


\title{
Discerning Trends, Contours, and Boundaries in Comparative Education: A Survey of Comparativists and Their Literature
}

\author{
BRADLEY J. COOK, STEVEN J. HITE, AND ERWIN H. EPSTEIN
}

Surely the health and vitality of any academic field relies on the periodic review of its intellectual history, evolving theoretical frameworks, and thematic shifts. Attempts to define a field typically involve lively debates over boundary maintenance. ${ }^{1}$ Indeed, the question of whether comparative education is a "discipline" has been debated at least since the earliest issues of the Comparative Education Review ${ }^{2}$ and has continued to be debated in different forums. ${ }^{3}$ Leon Tikly and Michael Crossley believe that a comparative and international canon is discernible, although it is one that is "continually being challenged by new theories and approaches from the arts, humanities, and social sciences, and its boundaries in this sense are fluid and permeable rather than hermetically sealed." 4

Many are the entreaties to alter the field. Michael Crossley and Peter Jarvis wish to reconceptualize comparative and international research, though doing so by building on the "positive" traditions gained from past experience. ${ }^{5}$

The research reported in this article relied heavily on the financial support of Utah Valley State College and the Department of Educational Leadership and Foundations at Brigham Young University. We express our sincere gratitude to those institutions and to our assistants. In particular, we want to thank Raija Kemppainen and her dedicated research team for their indefatigable efforts in gathering the data contained in this article under severe time and resource constraints.

Tables 1-12 and apps. A and B of this article may be found in the electronic edition of CER.

${ }^{1}$ This is a point illustrated much earlier with regard to comparative education in Robert Ulich, "The Challenge of Definitions in Comparative Education," Comparative Education Review 1 (October 1957): 3-4. See also Erwin H. Epstein, "The Problematic Meaning of 'Comparison' in Comparative Education," in Theories and Methods in Comparative Education, ed. Jürgen Schriewer and Brian Holmes (Frankfurt: Lang, 1988), pp. 3-24; Laadan Fletcher, "Comparative Education: A Question of Identity," Comparative Education Review 18 (October 1974): 348-53; Harold J. Noah and Max Eckstein, Doing Comparative Education: Three Decades of Collaboration (Hong Kong: Hong Kong University Press, 1998); W. D. Halls, ed., Comparative Education: Contemporary Issues and Trends (London: Kingsley, 1990); Philip Altbach, Robert Arnove, and Gail Kelly Comparative Education (New York: Macmillan, 1982).

${ }^{2}$ Katheryn G. Heath, "Is Comparative Education a Discipline?" Comparative Education Review 2 (October 1958): 31-32.

${ }^{3}$ See, e.g., Patricia Broadfoot, "Not So Much a Context, More a Way of Life? Comparative Education in the 1990s," in Learning from Comparing: New Directions in Comparative Educational Research, ed. R. J. Alexander, P. Broadfoot, and D. Phillips, vol. 1 of Contexts, Classrooms, and Outcomes (Oxford: Symposium, 1999), pp. 21-32.

${ }^{4}$ Leon Tikly and Michael Crossley, "Teaching Comparative and International Education: A Framework for Analysis," Comparative Education Review 45, no. 4 (2001): 564.

${ }^{5}$ Michael Crossley and Peter Jarvis, "Introduction: Continuity, Challenge and Change in Comparative and International Education," Comparative Education 36, no. 3 (2000): 261-65.

Comparative Education Review, vol. 48, no. 2.

(C) 2004 by the Comparative and International Education Society. All rights reserved.

0010-4086/2004/4802-0000\$05.00 
Patricia Broadfoot calls for a "neo-comparative education . . . in tune with the emerging new educational aspirations of the 21st century and the acknowledged shortcomings of conventional forms of educational provision." 6 Robert Cowen and Robin J. Alexander argue that themes of curriculum and pedagogy have been neglected and need to be brought vigorously into the field. ${ }^{7}$ Andreas M. Kazamias contends that history as a dimension in comparative education has been virtually abandoned and urges the "reinvention" of "the historical in comparative education." Such efforts to modify and redirect are not, of course, unique to comparative education but are common, in greater or lesser degree, to all dynamic scholarly fields. A few scholars, such as Immanuel Wallerstein, even advocate breaking the barriers separating academic disciplines. ${ }^{9}$ As a highly eclectic field that draws vigor from a large array of scholarly pursuits, comparative education is particularly susceptible to calls for change from all directions. ${ }^{10}$

The value of ongoing exhortations for directional change and modifications in the character of comparative education is difficult to judge in the absence of comprehensive assessments of what the field actually contains and what the field's practitioners actually believe is important. Confronting the many calls for change, some scholars have attempted to outline the field's evolving ideological perspectives and trends. ${ }^{11}$ Some have sought to impose a "Darwinian" interpretation of the field's development, claiming that comparative education has "progressed" from using older, less rigorous methods of study to newer, more scientific approaches. ${ }^{12}$ John N. Hawkins and Val D. Rust contend that newer theoretical orientations, including critical theory, post-structuralism, postmodernism, and feminist theories are successfully

\footnotetext{
${ }^{6}$ Patricia Broadfoot, "Comparative Education for the 21st Century: Retrospect and Prospect," Comparative Education 36, no. 3 (2000): 358.

${ }^{7}$ Robert Cowen, "Comparing Futures or Comparing Pasts?" Comparative Education 36, no. 3 (2000): 333-42; Robin J. Alexander, "Border Crossings: Towards a Comparative Pedagogy," Comparative Education 37, no. 4 (2001): 507-23.

${ }^{8}$ Andreas M. Kazamias, "Re-inventing the Historical in Comparative Education: Reflections on a Protean Episteme by a Contemporary Player," Comparative Education 37, no. 4 (2001): 439-49.

${ }^{9}$ See Alejandro Portes, "Sociology in the Hemisphere: Convergences and a New Conceptual Agenda," LASA [Latin American Studies Association] Forum 33, no. 1 (2002): 6-7.

${ }^{10}$ See Tony Beecher, Academic Tribes and Territories: Intellectual Enquiry and the Culture of Disciplines (Buckingham, U.K.: Open University Press, 1989).

${ }^{11}$ R. G. Paulston, "Comparative and International Education: Paradigms and Theories," in The International Encyclopedia of Education, ed. Torsten Husén and T. Neville Postlethwaite, 2d. ed. (Exeter: Pergamon, 1994): 2:923-33; Erwin H. Epstein, "Currents Left and Right: Ideology in Comparative Education" (presidential address), Comparative Education Review 27 (February 1983): 3-29; Andreas M. Kazamias and Karl Schwartz, "Intellectual and Ideological Perspectives in Comparative Education: An Interpretation," Comparative Education Review ("Special Issue: The State of the Art") 21 (June/October 1977): 153-76; Brian Holmes, "Paradigm Shifts in Comparative Education," Comparative Education Review 28 (November 1984): 584-604; Philip G. Altbach, "Trends in Comparative Education," Comparative Education Review 35 (August 1991): 491-507; Edmund King, "A Century of Evolution in Comparative Studies," Comparative Education 36 (August 2000): 267-78.

${ }^{12}$ See Epstein, "Currents Left and Right: Ideology in Comparative Education."
} 
challenging traditional orientations. ${ }^{13}$ Yet, such theories as postmodernism and post-structuralism can hardly be considered new, having their roots in pre-Socratic sophism. ${ }^{14}$ The many claims made by comparativists about the nature of their field are remarkable, because only rarely have they surveyed the field's constituents and contents to gauge the way comparative education is actually conceptualized.

There is, indeed, a paucity of comprehensive studies about the field, however large the debate over definitions and contours. And, as we show, whatever little research has been done in this regard has been inadequate. That these studies contain flaws is to be expected in view of the extraordinary time and resources required in such work. Our purpose is partly to avoid many weaknesses of previous studies, to use more systematic and appropriate methods to discern trends, contours, and boundaries.

All fields do, after all, have boundaries, or they would be indistinguishable from other fields. To be sure, boundaries in comparative education are difficult to apprehend because they are so fluid. Yet we feel obliged to make the effort. If comparativists do not share a common sense, however ambiguous, of their field's borders, how can they "teach" the field to new generations? Without such a sense of boundary, how can we know what is appropriate scholarly material to include in our journals and other forums? How, indeed, can we carry on meaningful discourse about the field?

Although we value epistemological analysis, we believe that a field's contours and boundaries are best discerned through assessing the thoughts and actions of the field's practitioners. Those who seek to alter comparative education cannot do so on their own; they must convince other comparativists of the need for change. It is ultimately not the seekers of change who change the field, but the practitioners themselves who choose to do so or choose to maintain boundaries as they are. Surely, then, the first order of business is to find out how comparativists conceptualize their field and the factors that might influence their thinking. Our study is then, first of all, on the condition of the field, its demographics, and its constituents' attendant perceptions of important themes, works, figures, universities, and organizations shaping the field.

To examine the field's contemporary dimensions, we conducted a survey of the members of the Comparative and International Education Society (CIES), the largest and oldest constituent organization of the World Council of Comparative Education Societies (WCCES), to discern how perceptions of the field converge. While we can do little to settle the obstinate existential questions preoccupying comparative education, we believe we can perhaps contribute a degree of understanding by establishing demographic data

\footnotetext{
${ }^{13}$ John N. Hawkins and Val D. Rust, "Shifting Perspectives on Comparative Research: A View from the USA," Comparative Education 37, no. 4 (November 2001): 501-6.

${ }^{14}$ Stuart Parker, Reflective Teaching in the Postmodern World: A Manifesto for Education in Postmodernity (Buckingham, U.K.: Open University Press, 1997), pp. 69-70.
} 
points in a particular part of that epistemic landscape-that of the CIES membership. It is, after all, the individuals in the profession who determine the field's contours. Unfortunately, we lack the means to survey the entire world body of comparativists. It is hoped, however, that future work will expand on the scope of the current study to include other comparativist societies. Indeed, it is hoped that this study will serve as a benchmark for broader "state-of-the-art" epistemic analyses of the field.

We structured our questions in such a way as to discern certain tendencies. To what extent do members of CIES work on common ground and from shared assumptions? How knowledgeable is the Society about the field of comparative education, and how has knowledge changed over the years? Is there a reasonably common body of knowledge that is taught as comparative education, or is content comprised of arbitrary selections of knowledge? In addition, we performed a survey of citations in the literature to reveal preferences in the nature of the scholarship. In using these devices we hope to reveal more accurately and comprehensively than did past studies the means by which comparative education is conceptualized in the minds of its constituency. At the very least, we believe, our study can provide important reference points for speculation about where comparative education might be headed in the future.

\section{Earlier Studies}

We begin our study with a review of the literature containing previous efforts to survey the field. Research in this area can be divided into three categories: (1) attitudinal surveys of practitioners, mainly about their objectives in practicing in the field, (2) surveys of course contents, and (3) citation analyses of the literature.

Until now, no study to our knowledge has attempted to cover all three categories, and the literature therefore contains only slender glimpses of our field. Nevertheless, however limited in scope and method these prior studies may be, they are valuable in yielding various profiles of comparative education.

Attitudinal Surveys

Scholars and practitioners of comparative education have been surveyed formally about their perspectives of the field only twice before-both times by a group of graduate students and faculty at the University of Michigan. ${ }^{15}$ The first survey was conducted at the March 21-23, 1979, CIES meeting in Ann Arbor, Michigan, and the second, using a slightly revised version of the questionnaire distributed at the Ann Arbor conference, was undertaken at

\footnotetext{
${ }^{15}$ Heidi Ross, Cho-Yee To, William Cave, and David E. Bair, "On Shifting Ground: The Postparadigm Identity of U.S. Comparative Education, 1979-88," Compare 22, no. 2 (1992): 113-31.
} 
the March 17-20, 1988, CIES meeting in Atlanta. Heidi Ross, Cho-Yee To, William Cave, and David E. Blair, the authors of the study, reported "remarkable continuity" and "startlingly similar" responses to identical items in the two surveys. ${ }^{16}$

The Ross et al. surveys focused on objectives, methods, and trends in comparative education, but mainly on the first of these-that is, objectives. The authors measured respondents' ratings of the importance of nine "major objectives reflected in comparative education literature during the late 1970 's" in terms of their significance to their own research and then in terms of their importance to the field. Respondents reported two objectives as being most important to their own research: "to study others' systems so that one may be better able to understand the tradition of one's own educational system and to revitalize and reform it" and "to appraise educational issues from a global rather than an ethnocentric perspective." In regard to the importance to the field, the objective that respondents reported as most significant was "to find facts about educational systems and to discern their direction of change-as a form of scholarship." ${ }^{17}$ Beyond these results, Ross et al. found as the most salient trend "the construction of community from diversity and acceptance of methodological eclecticism by comparative educators, and the field's internationalization and deinstitutionalization [which] suggest a potentially dramatic expansion of both the intellectual and institutional boundaries of comparative education." 18

The study by Ross et al. represents, as far as we know, the first and only systematic attempt, until the present investigation, to gauge the views of educational comparativists about their field. It is of great value, if for no other reason, because it furnishes a baseline of comparison for subsequent studies. Nevertheless, the study has limitations that must be taken into account if its findings are to be useful.

The study's most serious limitation relates to the reliability of results. Intuitively, we believe the findings accurately reflect the attitudes of comparativists at the time. The authors report that only 24 completed questionnaires were returned in the first survey, and only 35 were returned in the second. ${ }^{19}$ Without reporting the overall attendance at the 1979 and 1988 conferences, Ross et al. are unable to show the proportion of conference participants that the respondents represent, but it surely was not more than about 10 percent. If the respondents had been drawn as a random sample, the percentage would have been adequate, perhaps, for analyzing univariate data (which is all that Ross et al. apparently sought). Although the authors fail to report how the survey was conducted, we know from our own partic-

\footnotetext{
${ }^{16}$ Ibid., p. 114.

${ }^{17}$ Ibid., p. 115.

${ }^{18}$ Ibid., p. 114.

${ }^{19}$ Ibid., p. 129, nn. 5, 7.
} 
ipation in those conferences that respondents were asked at a table to complete the questionnaires. The investigators made a conscientious effort to gain the cooperation of conference participants, but we have no way of knowing the representativeness of their voluntary sample. Even more important, respondents were only from the CIES national meetings; no attempt was made to survey the membership at large, which was certainly much larger than, and plausibly varying in certain characteristics from, the population attending the conferences.

Ross et al. collected demographic data on the respondents but apparently did not use them. For one thing, such data could not be used to compare the sample with the overall population of comparativists (or, at least, those attending the two conferences) to verify reliability, since there was virtually no demographic information available on the CIES membership at large (or on participants at the conferences). For another thing, the sample was so small that the demographics would not yield valid results if correlated with the attitudinal variables. In other words, the investigators did not have enough respondents to address questions about, for example, how comparative education objectives might vary by such potentially influential characteristics as gender, disciplinary orientation, and time spent in the field.

Course Content Surveys

We are aware of two studies in this category. In 1994, Philip G. Altbach and Eng Thye Jason Tan conducted a worldwide survey of individuals, programs, and centers in comparative and international education. The questionnaire used was sent to 120 institutions. The work was essentially an inventory of programs: their enrollments, staff, locations, courses taught, and textbooks used. It contained little analysis. However, the authors identified five most commonly used textbooks in the field. This was merely a listing of materials by commonness of use; there was no effort to discern trends or correlate the order with individual or institutional characteristics. ${ }^{20}$

The second study, conducted shortly after that of Altbach and Tan, was by Heidi Ross, David Post, and Joseph Farrell. ${ }^{21}$ This survey reportedly reviewed 85 outlines of comparative and international education courses at all levels in 34 colleges and universities in the United States. ${ }^{22}$ The authors provide a wide-ranging and interesting discussion of the field's graduate programs, but their comments appear to be largely intuited from the survey;

\footnotetext{
${ }^{20}$ Philip G. Altbach and Eng Thye Jason Tan, Programs and Centers in Comparative and International Education: An International Inventory (Buffalo, N.Y.: SUNY—Buffalo Graduate School of Education, 1995).

${ }^{21}$ David Post, Joseph Farrell, and Heidi Ross, "Prologue to the Investigation of Comparative and International Education Graduate Programs in North America, Part I," CIES Newsletter, no. 108 (January 1995): 4, 14, 18; and Heidi Ross, David Post, and Joseph Farrell, "Prologue to the Investigation of Comparative and International Education Graduate Programs, Part II," CIES Newsletter, no. 110 (September 1995): 1, 4-5.

${ }^{22}$ Ross et al., "Prologue," p. 1. However, elsewhere the authors show only 12 institutions surveyed, one of which is not in the United States. Post et al., p. 18.
} 
reports of concrete findings were meager. Basically, they show that courses "divide roughly into seven categories" with "striking variability" in course content. ${ }^{23}$ They furnish no analysis to indicate the factors that produce that variability.

Citation Analyses

To our knowledge, Robert Koehl conducted what was heretofore the most comprehensive analysis of literature in comparative education. ${ }^{24}$ His study, in the mid-1970s, reviewed contents of three journals: the Comparative Education Review (1957-76), Comparative Education (1964-75), and the International Review of Education (1954-75). In viewing contents he did not limit himself to featured articles but also took into account book reviews, bibliographic notices, reports of conferences and other activities, and biographical notes. Hence, his analysis covered hundreds of articles and other types of content. Koehl's results included articles and book reviews sorted by topic category (from all three journals); a "morphology" of contents divided between "modern societies" and "developing societies" (Comparative Education Review only); the number of countries compared, sorted by the number of articles covering each number (Comparative Education Review only); and topics covered, sorted by frequency of appearance (Comparative Education Review only). However extensive and valuable were Koehl's findings, his analysis was "internal": limited to factors embodied in the journals' contents. He did not attempt to associate content variables with characteristics of authors or readers.

Val D. Rust, Aminate Soumaré, Octavio Pescador, and Megumi Shibuya investigated methodological trends displayed in articles from Comparative Education Review, Comparative Education, and the International Journal of Educational Development. They conclude that fewer than one-third of the studies they reviewed over a period of 25 years relied on direct comparisons as a research strategy. That is, they claimed that most research articles in the three leading journals they use to represent the field fail to be genuinely "comparative." ${ }^{25}$

More recently, Angela Little conducted a similar type of study, though much more limited in scope and analysis. ${ }^{26}$ She viewed the titles of all 472 articles appearing in the journal Comparative Education during the years 1977-98, classifying titles by country or countries, number of countries compared, and topic examined. This study was largely descriptive, with a modicum of internal analysis. As in Koehl's study, no effort was made to collect data

\footnotetext{
${ }^{23}$ Ross et al., "Prologue," p. 1.

${ }^{24}$ Robert L. Koehl, "The Comparative Study of Education: Prescription and Practice," Comparative Education Review ("Special Issue: The State of the Art") 21, nos. 2/3 (June/October 1977): 177-94.

${ }^{25}$ Val D. Rust, Aminate Soumaré, Octavio Pescador, and Megumi Shibuya, "Research Strategies in Comparative Education," Comparative Education Review 43, no. 1 (February 1999): 86-109.

${ }^{26}$ Angela Little, "Development Studies and Comparative Education: Context, Content, Comparison, and Contributors," Comparative Education 36, no. 3 (August 2000): 279-96.
} 
on authors' or readers' characteristics, notwithstanding the word "contributors" in the title of her work.

What, then, do these earlier studies show overall? Unsurprisingly, the attitudinal surveys have revealed a highly eclectic field with fluid boundaries but with a constituency unified around the objectives of understanding better the traditions of one's own system of education by studying those of others' and assessing educational issues from a global perspective. Course content surveys have shown few specifics about the content of what is taught in comparative education courses other than the existence of striking variability in the subject matter covered. Finally, citation analyses have yielded largely inconclusive results other than a dubious conclusion that the majority of articles published in comparative education journals are not "comparative." Our aim is to move beyond these earlier studies to arrive at a clearer understanding of the nature of comparative education. We do this in good part by tying our observations more closely to the voices of people in the field than has been done in the past.

\section{Methodology}

Before presenting the methods we employed, it is vital to acknowledge our most important guiding methodological principles. First, since earlier studies suffered from specific challenges, particularly, limited sample size and questionable representativeness, we determined to undertake a study that would have the largest possible sample size and represent the population of CIES membership as well as possible, given design and implementation limitations. Second, we wanted to be sensitive to the diversity that appears to be developing in CIES (shown in the earlier Ross et al. studies and to be further explored in this project). We anticipated that a diverse membership would also potentially need to have less, rather than more, constraint on the potential range in responses. Therefore, we were determined to leave the questions we asked as open to individual and diverse views as possible.

An unavoidable result of the flexible and open nature of the survey, however, was the need for a significant amount of creative data handling. We manipulated the data to render the responses into an analytical form that would lend itself to statistical techniques acceptable in the diverse multinational field of comparative education. We discuss this in more detail below but felt it important to assert at the outset, so that our methods, results, and conclusions could be viewed and interpreted in light of the hierarchy of priorities in the design of this project.

Nature of Instrumentation and Data

Our study consists mainly of two parts. The larger portion is a survey of background characteristics of the respondents and their perspectives on comparative education. Our survey instrument was a questionnaire of 16 questions 
(see app. A, which appears in the online edition of CER). The smaller portion is a collection of citations from three of the field's prominent journals: the Comparative Education Review, Comparative Education, and the International Journal of Educational Development. From this collection, we generated figures showing frequency of citations of authors in the field. We believe our study is the first to combine a citation analysis with sample survey results.

In our survey, we asked participants background questions that related to their gender, the highest degree they had earned, the year they had earned that degree, the field in which they had earned it, the year in which they had first joined a comparative education society, the geographic region of greatest research interest to them, their primary disciplinary emphasis, and whether they had ever taken or had ever taught an introductory comparative education course. We queried attitudes about the field regarding the importance of major themes, leading figures, leading works, leading universities, and leading organizations.

\section{Sampling and Data Collection}

The sample was drawn from the 2000 CIES membership directory, which includes listings for 1,345 individual members (405 international addresses and 940 U.S. addresses), ${ }^{27}$ of which we determined 853 to contain accurate and accessible contact information. In many cases, the listed contact information (address, telephone and/or fax number, e-mail address) was either incorrect or outdated. To collect data, multiple forms of communication were utilized. First, a mailed survey went to the accessible membership in February 2001. The response rate was less than 8 percent, likely because of the overall length of the instrument. A shorter version of the survey was created and disseminated via telephone and e-mail from May to August 2001. ${ }^{28}$ Only responses to questions that were common to all forms of the survey (traditional mail, e-mail, and telephone) were used in the analysis presented in this article. Overall, 419 usable responses were received, representing 49 percent of the 853 accessible members.

Of the 419 usable responses, 287 (69.3 percent) were from the United States $^{29}$ and 127 (30.6 percent) were non-U.S. respondents, ${ }^{30}$ with five respondents not identifying their place of residence. Most of the data were collected through the telephone survey format.

Because of the international character of the CIES membership, many

\footnotetext{
${ }^{27}$ This figure excludes institutional memberships.

${ }^{28}$ Technically defined, this study is based on a census with a response rate rather than on a sample of a population.

${ }^{29}$ Altogether, 316 domestic members were inaccessible because of faulty contact information.

${ }^{30}$ Non-U.S. responses represented 56 percent of the total international membership listed in the 2000 CIES directory. Altogether, 177 international members could not be contacted. This figure includes 134 international members who could not be found at all, 30 international members with incorrect telephone listings, and 13 who had only an e-mail address and whose e-mail surveys failed to deliver.
} 
of the surveys had to be conducted in a language other than English. ${ }^{31}$ Language biases were minimized in the telephone interviews by having a research staff that was fluent in Mandarin Chinese, Japanese, Spanish, Portuguese, Korean, French, German, Swedish, Finnish, and Russian.

We think our study is a methodological advance over previous studies and perhaps a logical next step in exploring the nature of the society of comparativists gathered under the umbrella of CIES. A variety of features make this study unique, not the least of which were efforts to contact every listed member of CIES using multiple techniques (mail, fax, e-mail, telephone), multiple times (at least three attempts per member, at diverse times of the day, over the course of a number of weeks or months), and in multiple languages.

Also, the open-ended structure of the central nondemographic survey questions allowed for tremendous range in responses (e.g., 550 themes, 537 works, and 451 figures were named as important and/or influential in the field of comparative education), as opposed to having the respondents rank order a prescribed number of preselected themes, works, figures, and so forth. We believe this range and flexibility qualify our study as a significant improvement in understanding important issues in the field and in providing an opportunity for CIES members to register their perspectives freely.

Data Treatment and Analysis

Demographic information was used both to produce tables describing the respondents' characteristics (as representing the CIES membership) and in the descriptive and inferential analyses regarding the survey's other thematic elements. The data on themes, works, figures, universities, and organizations, however, presented a more interesting and ultimately fruitful challenge. Five "top-ten" lists were constructed by transforming the open-ended responses into ordinal and then interval data indicating to what degree each respondent contributed to the 10 most frequent responses in each category. Thus, each respondent could have contributed anywhere from zero to five responses to each of the five lists.

In investigating possible relationships, a number of analytical procedures were used, depending on the type of data involved. Chi-squared procedures were used for strictly nominal variables, Polytomous Logit Universal Models (PLUM) were used for ordinal outcome data, Pearson correlation analyses were used for interval variables, and $t$-tests and ANOVAs were used when there were interval dependent variables with nominal independent variables. The primary focus in these procedures was to explore potential relationships in the data with a particular interest in the identification of the themes, works, figures, universities, and organizations.

\footnotetext{
${ }^{31}$ While most members in this category have sufficient language facility to participate in CIES activities and can read English, a portion did exhibit difficulty in communicating in oral English.
} 
The results of the overall analysis, then, are presented in several forms. We present the results of the analyses of the thematic content (top-ten lists) of the survey in standard descriptive tables. Our inferential analyses, using rank-order formats, are explained in the text and supported by notes at the bottom of the tables.

\section{Findings and Discussion}

This section contains three parts: (1) CIES demographics, (2) five major content elements, and (3) relationships between the demographics and the five elements.

\section{CIES Demographics}

To the extent that professional organizations such as the Comparative and International Education Society can be seen as organizational representatives of the field (or at least aspects of it), one can observe through this survey the field's heterogeneous and eclectic nature. Although the survey respondents consisted mostly of North American (75.1 percent) academics and students (see table 1, which appears in the online edition of CER), a substantial amount of diversity was revealed in its disciplinary composition and research interests.

The demographics of the field suggest that women are becoming more equally a part of the disciplinary conversations, comprising over 46 percent of the total sample (see table 2, which appears in the online edition of $C E R$ ), which represents an increase of over 6 percent since 1997, when the CIES Gender and Education Committee reported female participation at 40 percent. ${ }^{32}$ Further, the survey's 46 percent is reflective of female authorship within the Society's journal, the Comparative Education Review, which reported that by the year 2000, 48 percent of the featured articles were produced by women. ${ }^{33}$

We categorized the 419 survey respondents into 75 groups based on the field in which they reported having earned their highest degree (see table 3 , which appears in the online edition of $C E R$ ). The academic field in which the greatest number of CIES members had earned their highest degree was comparative education (15.5 percent), followed by international education (8.2 percent) and educational planning ( 5.8 percent). Most of the remainder of the sample indicated that they hold degrees in social science disciplines such as sociology, economics, psychology, and political science.

The survey reveals 211 areas of primary disciplinary emphasis (reduced to 80 for the analysis), with the largest category (i.e., educational policy and

\footnotetext{
${ }^{32}$ Erwin H. Epstein, “Comparative Education Review Annual Report for 1997," report submitted to the CIES Board of Directors, 1998.

${ }^{33}$ John Hawkins, "Comparative Education Review Annual Report for 1999," report submitted to the CIES Board of Directors, March 2000, p. 10.
} 
planning) having only about 17 percent of respondents (see table 4, which appears in the online edition of $C E R$ ). Although comparative education is the field in which the largest percentage of respondents received their degree, that field is only the fifth most common disciplinary emphasis reported (see tables 3 and 4 in the online edition of $C E R$ ). Even if we combined comparative international studies, international education/exchange, and theory (presumably in comparative education), that combined category would be only the third most frequently listed.

Nearly one-third of respondents indicated they had no specific region that was foremost as a research interest but rather had multiregional interests. Of those indicating a single regional interest, about 23 percent listed Asia, 14 percent indicated Latin America, and slightly more than 13 percent listed Africa. Europe and North America (the United States and Canada) were represented by about 11 percent and 4.6 percent, respectively (see table 5 , which appears in the online edition of $C E R$ ).

That nearly one out of three respondents had multi- or cross-regional interests is surprising, given the relative youth of Society members. Intuitively, it would seem that a multiregional research interest would be more typical of senior-level scholars, whose careers have allowed them to extend beyond the generally narrow geographical emphases of their doctoral work. Perhaps this breadth indicates that the training and development of new scholars is quite broad in geographical focus, or that the ease of travel, communication, and information distribution facilitate this broad geographical interest. It is also possible that an increasingly competitive job market necessitates broader geographical expertise, and new scholars are trying to maximize their employment opportunities.

The largest clustering of current positions held by respondents is faculty (tenured, tenure-track, instructor, or retired), at about 57 percent (see table 6 , which appears in the online edition of $C E R$ ). The next largest grouping is students, at almost 23 percent, most at the doctoral level. Other positions represented include administrators, at almost 5 percent; emeritus or retired, at somewhat more than 4 percent; and international agency specialists, at about 2 percent. The overwhelming majority of respondents (94.5 percent) hold advanced degrees, with almost 64 percent possessing a doctorate (see table 7, which appears in the online edition of $C E R$ ).

The field is also characterized by diversity in the universities at which its members are academically trained. Respondents identified 178 universities at which they received their highest academic degree. Stanford University and Harvard University, each with about 6 percent of the total, were the most frequently named universities for degree training, but no institution can claim to produce comparative educationists in any large number (see table 8, which appears in the online edition of $C E R$ ).

One of the most striking findings of this study is how relatively young 
the current membership is, with somewhat more than 44 percent having received their highest academic degree since 1992 (see table 9, which appears in the online edition of CER). The median year was 1990, with a mode of 1998. Yet the range in "year of highest degree" was large-51 years-with the earliest degree received in 1950 and the most recent in 2001. It is also interesting that most respondents received their degrees after 1990 or before 1970; the 1980s appear to have been a lean decade. Another indication of the relative youth of the field was the date when respondents first joined a comparative education society, most having done so after 1990 (55.4 percent). The earliest date a respondent had joined a comparative education society was 1958, and the most recent was 2001. The median year for the sample was 1994 (see table 10, which appears in the online edition of CER).

To what extent have people in the field been engaged in the formal teaching or learning of comparative education? It is of considerable note that, although over half of the sample (53 percent) was engaged in teaching (i.e., they were tenure-track faculty or instructors), fewer than two-thirds had never taught an introductory comparative education course (see table 11, which appears in the online edition of $C E R$ ), and fewer than two-thirds never had taken even an introductory course in comparative education (see table 12 , which appears in the online edition of $C E R$ ).

The "picture" of comparative education painted by these demographics indicates a field and professional cohort confronting several substantial challenges. With a young membership that is increasing in diversity (gender, content focus, institutional background, geographical research breadth, etc.), several salient questions arise for those who are interested in the field in general and in CIES in particular. These questions relate to the profession's functional influence on content and standards in educational institutions and field-based practice and research. In particular, we list the following:

What sense of, or connection to, the history of comparative education do comparativists have, and do they see that history as positive or negative?

Can the knowledge base, values, and accumulated wisdom of past members be passed on to the rising generation of comparativists, or should they be passed on?

Where are the "centers of influence" that produce this next generation of comparativists, and what influence do they have in answering the previous questions?

We believe the issues raised and explored regarding comparativists' perspectives on influential themes, works, figures, universities, and organizations provide a vital foundation for pursuing answers to these questions.

Five Major Content Elements

The CIES membership responding to the survey identified a tremendous range of themes (550), works (537), figures (471), universities (240), and 
organizations (743). Within this diverse, relatively centerless depiction of comparative education are issues of boundary maintenance. To what degree do perceptions concerning themes, important works, figures, and institutions converge to give shape and substance to the field?

Themes.-Our survey found few consensual answers within the Society as to what themes are considered salient to the current state of comparative education. Globalization and gender, with each named by somewhat less than 8 percent of respondents, were the top-listed clustered general themes, but clustered themes encompassed some 550 individual topics (table 13). Respondents reached little consensus, too, on their view of themes not adequately accounted for currently in comparative education (table 14). Only two themes, "gender in education" and "methodology/epistemology," appeared on both lists. In other words, respondents overall considered only these two themes to be among the most important and, at the same time, the most neglected.

Important works. - Over the years, comparative education has developed a body of literature that can be investigated to ascertain patterns of the field's growth, the advent of schools of thought, and the building of a knowledge base. An examination of the literature affords insights into the contribution of specific authors and published works from which to view the field's intellectual history. In our survey we asked respondents to list, based on their opinion, the most influential works and figures in comparative education. Again, there was considerable information scatter, with 537 works listed. Table 15 shows the 22 most frequently named works. It is worth noting that many of these works are currently out of print but still enjoy a measure of durability. We speculate that these works endure not because they are easily accessible but because they are widely cited. Also, comparative education courses rarely

TABLE 13

The 10 Most Frequently Named Themes in Comparative Education

\begin{tabular}{lccc}
\hline Theme & Frequency & $\begin{array}{c}\text { Percentage of } \\
\text { Total Responses }\end{array}$ & $\begin{array}{c}\text { Cumulative } \\
\text { Percentage }\end{array}$ \\
\hline Globalization & 105 & 7.9 & 7.9 \\
Gender in education & 101 & 7.6 & 15.5 \\
Education and development & 62 & 4.6 & 20.1 \\
Equality in education & 54 & 4.0 & 24.1 \\
Multiculturalism, race, and ethnicity & 49 & 3.7 & 27.8 \\
Methodology/epistemology & 43 & 3.2 & 31.0 \\
Change and reform & 42 & 3.1 & 34.1 \\
Economics, microcredit, privatization & 39 & 2.9 & 39.0 \\
Funding/development & 37 & 2.8 & 42.3 \\
Policy/politics/planning & 33 & 2.5 & \\
\cline { 2 - 4 } Total & 565 & 42.3 & \\
\hline
\end{tabular}

Note. - There were 550 themes listed in the responses; these were clustered into 75 general themes for this analysis. 
TRENDS IN COMPARATIVE EDUCATION

TABLE 14

Themes Not Adequately Accounted for in Comparative Education

\begin{tabular}{lccr}
\hline Theme & Frequency & $\begin{array}{c}\text { Percentage of } \\
\text { Total Responses }\end{array}$ & $\begin{array}{r}\text { Cumulative } \\
\text { Percentage }\end{array}$ \\
\hline Comparative studies (topics and levels) & 26 & 4.7 & 4.7 \\
Country/area studies & 23 & 4.2 & 8.9 \\
Methodology/epistemology & 21 & 3.8 & 12.7 \\
Language policy & 20 & 3.6 & 16.3 \\
Gender in education & 19 & 3.5 & 19.8 \\
Nonformal education & 17 & 3.1 & 22.9 \\
Higher education & 15 & 2.6 & 25.5 \\
Role of government and nongovern- & & 2.6 & 28.1 \\
$\quad$ mental organizations & 15 & 2.1 & 30.2 \\
Technology in education & 14 & 2.1 & 32.3 \\
Theory & 14 & 32.3 & \\
\multicolumn{1}{l}{ Total } & 184 & & \\
\hline
\end{tabular}

NoтE. - There were 550 themes listed in the responses; these were clustered into 75 general themes for this analysis.

use textbooks, but instead assign readings from these works. Consequently, they are read, often in pieces, even if they are not purchased.

As a counteranalysis, we conducted a bibliometric study to compare this list with works actually being cited by scholars in comparative education. The basic assumption in such an analysis is that more commonly cited works are typically considered more important by scholars within the field.$^{34}$ We used the Social Sciences Citation Index to search references in three prominent, refereed journals in comparative education: the Comparative Education Review (CER), Comparative Education (CE), and the International Journal of Educational Development (IJED). ${ }^{35}$

Unlike self-contained disciplines, comparative education is typified by interdisciplinary cross-pollination. Thus a second, broader search was conducted to include all scholarly works within the Social Science Citation Index. Such an analysis provides insight into the intradisciplinary and/or interdisciplinary impact of the work. While our study is limited to influential figures and works within the field of comparative education, all of the listed figures or works have had a degree of contributive influence across a variety of other

\footnotetext{
${ }^{34}$ Citation counts say nothing of the quality of a cited work or of an author's intention in citing a particular work. Nevertheless, viewed within proper constraints they can provide useful insights into a particular literature. The number of times an author or work is actually cited by others in a field is an often used practical measure of that author's direct or indirect impact. An author may be widely cited because others are citing one (or a few) of her or his publications often or because they are citing each of a large number of her or his works a few times.

${ }^{35}$ Admittedly, other journals might legitimately have been included in the study. Comparative Education Review was included because it is the sponsored organ of the association targeted by this survey, the Comparative and International Education Society. Comparative Education was included since it is published in the United Kingdom and thus represents a non-North American arm of the field. International Journal of Educational Development was included because of its general emphasis on education for development, an integral dimension of the field less represented in either CER or $C E$. This citation study coded and analyzed citations given as footnotes or references in the above three journals.
} 
COOK, HITE, AND EPSTEIN

TABLE 15

The 22 Most Influential Works in Comparative Education

\begin{tabular}{|c|c|c|c|}
\hline Work & Frequency & Percentage & $\begin{array}{l}\text { Cumulative } \\
\text { Percentage }\end{array}$ \\
\hline Friere, P. (1970). Pedagogy of the Oppressed. & 32 & 3.6 & 3.6 \\
\hline $\begin{array}{l}\text { Noah, H. J., and Eckstein, M. A. (1969). Toward a Science of } \\
\text { Comparative Education. }\end{array}$ & 26 & 2.9 & 6.5 \\
\hline $\begin{array}{l}\text { Altbach, P. G., and Kelly, G. P., eds. (1986). New Approaches } \\
\text { to Comparative Education. }\end{array}$ & 17 & 1.9 & 8.4 \\
\hline $\begin{array}{l}\text { Altbach, P. G., Arnove, R. F.,, and Kelly, G. P., eds. (1982). } \\
\text { Comparative Education. }\end{array}$ & 17 & 1.9 & 10.3 \\
\hline Arnove, R., and Torres, C. (1999). Comparative Education: & & & \\
\hline The Dialectic of the Global and the Local. & 16 & 1.8 & 12.1 \\
\hline Carnoy, M. (1974). Education as Cultural Imperialism. & 16 & 1.8 & 13.9 \\
\hline Journal: Comparative Education Review. & 16 & 1.8 & 15.7 \\
\hline Bereday, G. Z. F. (1964). Comparative Method in Education. & 15 & 1.7 & 17.4 \\
\hline Kandel, I. L. (1933). Comparative Education. & 12 & 1.4 & 18.8 \\
\hline King, E. J. (1958). Other Schools and Ours. & 10 & 1.1 & 19.9 \\
\hline $\begin{array}{l}\text { Arnove, R. F., Altbach, P. G., and Kelly, G. P. (1978). Emer- } \\
\text { gent Issues in Education: Comparative Perspectives. }\end{array}$ & 9 & 1.0 & 20.9 \\
\hline Altbach, P. G., and Kelly, G. P. (1978). Education and & & & \\
\hline Colonialism. & 8 & .9 & 21.8 \\
\hline Coombs, P. H. (1963). The World Crisis in Education. & 8 & .9 & 22.7 \\
\hline $\begin{array}{l}\text { Hans, N. A. (1949). Comparative Education: A Study of Educa- } \\
\text { tional Factors and Traditions. }\end{array}$ & 8 & .9 & 23.6 \\
\hline Works by Altbach, P. G. & 7 & .8 & 24.4 \\
\hline Works by Arnove, R. F. & 7 & .8 & 25.2 \\
\hline Works by Carnoy, M. & 7 & .8 & 26.0 \\
\hline Carnoy, M. (1990). Education and Transition in the Third & & & \\
\hline World. & 6 & .7 & 26.7 \\
\hline Journal: Comparative Education. & 6 & .7 & 27.4 \\
\hline Holmes, B. (1965). Problems in Education: A Comparative & & & \\
\hline Approach. & 6 & .7 & 28.1 \\
\hline Paulston, R. G. (1996). Social Cartography: Mapping Ways of & & & \\
\hline Seeing Social and Educational Change. & 6 & .7 & 28.8 \\
\hline Works by Stromquist, N. & 6 & .7 & 29.5 \\
\hline Total & 261 & 29.5 & \\
\hline
\end{tabular}

Note. - There were 537 works named by the respondents.

social science disciplines (esp. sociology, economics, political science, and anthropology, as well as history).

Table 16 shows the citation frequency of individual published works regardless of the author's other contributions. This phase of the study found notable differences between what scholars in the field perceive as most important and what they actually cite in their scholarly literature.

Important figures.-That a particular work may have large citation frequencies and/or be perceived as being influential does not necessarily reveal the overall impact the author has had on the field. An author or body of work may be one of the most cited because of one particular work. An author may exert influence on the field by the cumulative impact of a large number of published and cited works, by leadership within the field's professional associations, or by historical placement. Thus, to discern impact, respondents 
TRENDS IN COMPARATIVE EDUCATION

TABLE 16

Summary of Cited Works

\begin{tabular}{|c|c|c|}
\hline Book & $\begin{array}{l}\text { References } \\
\text { in Indicated } \\
\text { Journals* }\end{array}$ & $\begin{array}{l}\text { Total } \\
\text { References }\end{array}$ \\
\hline Carnoy, M. (1974). Education as Cultural Imperialism. & 56 & 256 \\
\hline $\begin{array}{l}\text { Noah, H. J., and Eckstein, M. A. (1969). Toward a Science } \\
\text { of Comparative Education. }\end{array}$ & 30 & 62 \\
\hline Friere, P. (1970). Pedagogy of the Oppressed. & 27 & 1,118 \\
\hline Bereday, G. Z. F. (1964). Comparative Method in Education. & 22 & 44 \\
\hline King, E. J. (1958). Other Schools and Ours. & 20 & 36 \\
\hline $\begin{array}{l}\text { Altbach, P. G., Arnove, R. F., and Kelly, G. P., eds. } \\
\text { (1982). Comparative Education. }\end{array}$ & 16 & 26 \\
\hline Kandel, I. L. (1933). Comparative Education. & 14 & 27 \\
\hline $\begin{array}{l}\text { Arnove, R., and Torres, C. (1999). Comparative Education: } \\
\text { The Dialectic of the Global and the Local. }\end{array}$ & 7 & 10 \\
\hline $\begin{array}{l}\text { Altbach, P. G., and Kelly, G. P. (1986). New Approaches to } \\
\text { Comparative Education. }\end{array}$ & 5 & 30 \\
\hline Total & 308 & 1,951 \\
\hline
\end{tabular}

* Comparative Education Review, International Journal of Educational Development, and Comparative Education. This information from the Social Science Citation Index is current as of May 2, 2002. This listing evaluates citation counts of only the nine most influential books listed in table 15 and reorders them based on citation frequency.

to the survey were asked who, in their opinion, were the most influential figures in comparative education. As with other opinion questions, respondents were given the opportunity to provide up to five answers. Table 17 shows the 21 most frequently named figures, with fewer than half of the respondents naming any of these. In all, 451 different figures were named, suggesting yet again a substantial range and variety of opinions.

A citation analysis reveals a somewhat different ordering of who is considered most influential (table 18). Nevertheless, a comparison of table 18 with appendix B (which appears in the online edition of CER) shows that the disparity between the survey ranking and the citation frequency is not as large as it is in regard to most influential works (table 15). Notable in these tables is the fact that the vast majority of both figures and works deemed influential have been from the post-World War II era (the exception being Isaac Kandel). Nineteenth-century figures critical to the establishment of the field, such as Marc-Antoine Jullien de Paris, Victor Cousin, and Michael Sadler, did not register among the most important figures. This suggests plausibly that the respondents overall have a weak sense of the field's history, and/or are likely impacted by the field's current demographics relating to gender and field of training and emphasis. ${ }^{36}$

Universities.-One objective of this study was to obtain impressions from the field as to which universities and organizations (from any country) have

\footnotetext{
${ }^{36}$ There are more women in CIES than in the past, and, as will be shown in the next section, female respondents differ significantly from males in their views regarding which works and figures are most important.
} 
COOK, HITE, AND EPSTEIN

TABLE 17

The 21 Most Influential Figures in Comparative Education

\begin{tabular}{|c|c|c|c|}
\hline Figure & Frequency & $\begin{array}{l}\text { Percentage of } \\
\text { Total Responses }\end{array}$ & $\begin{array}{l}\text { Cumulative } \\
\text { Percentage }\end{array}$ \\
\hline Philip Altbach & 83 & 5.8 & 5.8 \\
\hline Martin Carnoy & 65 & 4.5 & 10.3 \\
\hline Robert Arnove & 52 & 3.6 & 13.9 \\
\hline Harold Noah & 47 & 3.3 & 17.2 \\
\hline George Bereday & 42 & 2.9 & 20.1 \\
\hline Nelly Stromquist & 38 & 2.6 & 22.1 \\
\hline Paulo Freire & 36 & 2.5 & 25.2 \\
\hline Erwin Epstein & 32 & 2.2 & 27.4 \\
\hline Gail Kelly & 28 & 1.9 & 29.3 \\
\hline Ruth Hayhoe & 27 & 1.9 & 31.2 \\
\hline Carlos Torres & 25 & 1.7 & 32.9 \\
\hline Diane Hoffman & 21 & 1.5 & 34.4 \\
\hline Edmund King & 21 & 1.5 & 35.9 \\
\hline Max Eckstein & 20 & 1.4 & 37.3 \\
\hline Isaac Kandel & 20 & 1.4 & 38.7 \\
\hline Noel McGinn & 18 & 1.3 & 40.0 \\
\hline George Psacharopoulos & 18 & 1.3 & 41.3 \\
\hline Philip Foster & 17 & 1.2 & 42.5 \\
\hline Don Adams & 15 & 1.0 & 43.5 \\
\hline C. Arnold Anderson & 15 & 1.0 & 44.5 \\
\hline Torsten Husén & 15 & 1.0 & 45.5 \\
\hline Total & 655 & 45.5 & \\
\hline
\end{tabular}

NoтE. - There were 451 figures named by the respondents.

had the greatest influence on comparative education. Respondents were asked to identify up to five universities and five organizations. Of the 240 different organizations identified by respondents, Stanford University was listed most frequently (13.7 percent), followed Columbia (9.1 percent), Harvard (8.2 percent), University of Chicago (6.4 percent), and University of California, Los Angeles (5.9 percent; see table 19). It is noteworthy that five of the 10 universities from which the greatest numbers of the respondents received their highest degree (University of Michigan; University of Minnesota; University of California, Berkeley; University of Wisconsin; and New York University; see table 8 online) are not listed among the 10 universities perceived as the most influential. By contrast, one institution-the University of Chicago-is on both the list of the most influential universities and the list of the universities that granted the greatest number of our respondents their highest degrees, yet it no longer has a degree program in comparative education and is therefore no longer producing degree holders. These figures are signs of shifting sands, and perhaps illustrate the transient history of comparative education programs within the United States.

Other organizations. - In addition to those universities responsible for training professional comparativists, the respondents were asked to list what they considered to be the most influential governmental and nongovernmental organizations impacting the field. Out of the 188 different organizations listed 
TRENDS IN COMPARATIVE EDUCATION

TABLE 18

Summary of Cited Figures

\begin{tabular}{lcr}
\hline Author & $\begin{array}{c}\text { References in } \\
\text { Indicated Journals* }\end{array}$ & Total References \\
\hline Martin Carnoy & 140 & 1,351 \\
Philip G. Altbach & 100 & 656 \\
Paulo Freire & 97 & 3,283 \\
Robert F. Arnove & 82 & 252 \\
Harold J. Noah & 55 & 131 \\
Gail Paradise Kelly† & 50 & 1,067 \\
Nelly P. Stromquist & 41 & 144 \\
George Z. F. Bereday & 40 & 120 \\
Ruth Hayhoe & 39 & 137 \\
Erwin H. Epstein & 34 & 412 \\
\multicolumn{1}{c}{ Total } & 1,380 & 15,395 \\
\hline
\end{tabular}

Note. - This listing evaluates the citation counts of only the 10 most frequently cited authors listed in table 17 and reorders them based on citation frequencies. * Comparative Education Review, International Journal of Educational Development, and Comparative Education This information from the Social Science Citation Index is current as of May 2, 2002.

$\dagger$ Because of the potentially common nature of the name "G. Kelly," the total reference count for this name may include authors other than Gail Paradise Kelly.

by the sample, the World Bank was identified as having the most influence (19.7 percent). In addition, UNESCO (almost 15.8 percent), USAID (7.8 percent), UNICEF (5.0 percent), and the United Nations ( 3.7 percent) were the five most frequently listed as influential (see table 20).

Relationships between the Demographics and the Five Elements

Our results uncovered several general trends. It quickly became clear, and it was confirmed across most of the different types of analysis, that four demographic variables had consistent relationships with nearly all of the five content elements (themes, works, figures, universities, and organizations):

1. Gender;

2. Whether the respondent had ever taken a comparative education course;

3. Whether the respondent had ever taught a comparative education course;

4. The year in which the respondent first joined a comparative education society.

Before discussing our most important findings, it is essential to note that there were no statistically significant differences in the contributions made to the top-ten lists based on respondents' disciplinary emphasis. The only exception in this regard was in the "works" variable, where respondents designating the comparative, international, or planning emphasis contributed more frequently to the 10 most important works list than did respondents with other disciplinary emphases $(p<.01)$.

The other important "nonfinding" was that the geographical region of research interest had no statistically significant impact on the contribution 
COOK, HITE, AND EPSTEIN

TABLE 19

The 10 Most Influential Universities in Comparative Education

\begin{tabular}{lcrc}
\hline University & Frequency & $\begin{array}{c}\text { Percentage of } \\
\text { Total Responses }\end{array}$ & $\begin{array}{c}\text { Cumulative } \\
\text { Percentage }\end{array}$ \\
\hline Stanford University & 179 & 13.7 & 13.7 \\
Columbia University & 118 & 9.1 & 22.8 \\
Harvard University & 107 & 8.2 & 31.0 \\
University of Chicago & 83 & 6.4 & 37.4 \\
University of California, Los Angeles & 77 & 5.9 & 43.3 \\
University of London Institute of Education & & 48.4 \\
$\quad$ and Kings College & 66 & 5.1 & 53.0 \\
University of Pittsburgh & 60 & 4.6 & 56.9 \\
University of Toronto, Ontario Institute for & & 3.9 & 60.4 \\
$\quad$ Studies in Education & 51 & 3.5 & 62.5 \\
State University of New York-Buffalo & 45 & 2.1 & \\
Florida State University & 21 & 62.5 & \\
$\quad$ Total & 807 & & \\
\hline
\end{tabular}

Note. - There were 240 universities named by the respondents.

to the top-ten lists, except in the case of influential organizations. In this one case, those respondents who had "Africa" as a primary research interest contributed more to the top-ten list of influential organizations than those with a multiregional research interest $(p<.03)$, but all other between-group differences based on geographical research interest were not statistically significant.

The variables of geographical area of residence, field of highest degree, and current position yielded inconsistent results across the five top-ten lists. When these three were used as independent variables, the results were nearly evenly mixed in terms of whether there were differences in their association with contributions to the five top-ten lists.

TABLE 20

The 10 Most Influential Governmental and Nongovernmental Organizations in Comparative Education

\begin{tabular}{lccc}
\hline Organization & Frequency & $\begin{array}{c}\text { Percentage of } \\
\text { Total Responses }\end{array}$ & $\begin{array}{c}\text { Cumulative } \\
\text { Percentage }\end{array}$ \\
\hline World Bank & 230 & 19.7 & 19.7 \\
UNESCO & 185 & 15.8 & 35.5 \\
U.S. Agency for International Development & & 43.3 \\
$\quad$ (USAID) & 91 & 7.8 & 48.3 \\
UNICEF & 59 & 5.0 & 52.0 \\
United Nations & 43 & 3.7 & 55.5 \\
Organization for Economic Cooperation and & & 3.5 & 58.4 \\
$\quad$ Development (OECD) & 41 & 2.9 & 60.4 \\
CIES & 33 & 2.0 & 62.2 \\
Ford Foundation & 23 & 1.8 & 63.7 \\
Academy for Educational Development (AED) & 21 & 1.5 & \\
International Monetary Fund (IMF) & 17 & 63.7 & \\
$\quad$ Total & 743 & & \\
\hline
\end{tabular}

NoTE. - There were 188 organizations named by the respondents. 
TRENDS IN COMPARATIVE EDUCATION

TABLE 21

Top 10 Themes by Gender: Combined And Disaggregated Rankings

\begin{tabular}{|c|c|c|c|c|c|}
\hline \multirow[b]{3}{*}{ Theme } & \multirow{3}{*}{$\begin{array}{c}\text { Combined } \\
\text { Rank }\end{array}$} & \multicolumn{4}{|c|}{ Gender } \\
\hline & & \multicolumn{2}{|c|}{ Male } & \multicolumn{2}{|c|}{ Female } \\
\hline & & $N$ & Rank & $N$ & Rank \\
\hline Globalization & 1 & 56 & 1 & 48 & 2 \\
\hline Gender in education & 2 & 41 & 3 & 60 & 1 \\
\hline Equality in education & 3 & 25 & 6 & 29 & 3 \\
\hline Multiculturalism, race, and ethnicity & 4 & 37 & 4 & 22 & 4 \\
\hline Methodology/epistemology & 5 & 36 & 5 & 16 & 6 \\
\hline Education and development & 5 & 44 & 2 & 18 & 5 \\
\hline Education change and reform & 7 & 25 & 6 & 16 & 6 \\
\hline Economy, microcredit, and privatization & 8 & 25 & 6 & 14 & 9 \\
\hline Funding of education/development & 9 & 21 & 10 & 16 & 6 \\
\hline Theory & 10 & 23 & 9 & 6 & 10 \\
\hline Responses & 558 & 313 & & 245 & \\
\hline
\end{tabular}

Note. - Chi-square $=26.101(p<.01)$.

Gender--Male respondents consistently contributed more to the top-ten lists of works, figures, universities, and organizations, with the contribution rate for each list significant at the $p<.01$ level. Only in the case of contribution to the top-ten list of salient themes was there no significant gender trend.

There were also differences based on gender in how the top ten themes, works, figures, universities, and organizations were ranked. Tables 21-25 show how these five elements were ranked without considering gender, and then they show how female and male respondents differentially ranked the same components of the lists for each of the five content elements of the survey.

Having taken a comparative education course.-Respondents who had taken a comparative education course had a significantly higher contribution to all of the five top-ten lists than respondents who had never taken such a course (significant at the $p<.01$ level, except for the top-ten themes element, which was statistically significant at the $p<.03$ level).

Although those who had taken a course in comparative education contributed more to all five content elements, there were no significant differences in how they priority-ranked these elements compared to those who had not taken a course. This held true for all types of analysis on the ranking (ordinal) data for this variable.

Having taught a comparative education course.-The $t$-test analyses predictably showed that those who had taught an introductory comparative education course at some time in their career contributed more to each of the five top-ten lists than those who had never done so $(p<.01)$. When top-ten choices were analyzed, those who had taught a comparative education course at some point in their career ranked three content elements-works, figures, and universities-differently than those who had not (see tables 26-28). ${ }^{37}$

\footnotetext{
${ }^{37}$ We show no tables for themes and organizations, as we observed no influence on these elements of the variable "having taught a comparative education introductory course."
} 
COOK, HITE, AND EPSTEIN

TABLE 22

Top 10 Works by Gender: Combined AND Disaggregated Rankings

\begin{tabular}{|c|c|c|c|c|c|}
\hline \multirow[b]{3}{*}{ Work } & \multirow{3}{*}{$\begin{array}{c}\text { Combined } \\
\text { Rank }\end{array}$} & \multicolumn{4}{|c|}{ Gender } \\
\hline & & \multicolumn{2}{|c|}{ Male } & \multicolumn{2}{|c|}{ Female } \\
\hline & & $N$ & Rank & $N$ & Rank \\
\hline Freire $(1970)$ & 1 & 17 & 2 & 15 & 1 \\
\hline Noah and Eckstein (1969) & 2 & 20 & 1 & 5 & 7 \\
\hline Altbach and Kelly (1986) & 3 & 11 & 4 & 6 & 5 \\
\hline Altbach, Arnove, and Kelly (1982) & 4 & 7 & 9 & 10 & 2 \\
\hline Arnove and Torres (1999) & 5 & 9 & 7 & 7 & 3 \\
\hline Carnoy (1974) & 6 & 8 & 8 & 7 & 3 \\
\hline Comparative Education Review & 7 & 10 & 6 & 6 & 5 \\
\hline Bereday (1964) & 8 & 14 & 3 & 1 & 9 \\
\hline Kandel (1933) & 9 & 11 & 4 & 1 & 9 \\
\hline King (1958) & 10 & 6 & 10 & 4 & 8 \\
\hline Responses & 175 & 113 & & 62 & \\
\hline
\end{tabular}

Note. - Chi-square value $=19.21(p<.02)$.

Year respondent first joined a comparative education society.-For all five content elements, there was a statistically significant, negative correlation $(p<.01)$ between when a respondent first joined a comparative education (CE) society and the magnitude of their contribution to the top-ten lists. That is, the earlier a person first joined a $\mathrm{CE}$ society, the higher their contribution to the lists.

The intuitively obvious fact that the year the respondents received their highest degrees correlates highly with the year that the respondents first joined a CE society was confirmed statistically. Yet, the year of highest degree manifested a significant $(p<.01)$ relationship with only two of the five elements: influential works and universities.

\section{Conclusions}

The overall intention of this study is to better apprehend how comparativists themselves conceptualize their field and what themes, works, figures, universities, and organizations are perceived as important. Several issues emerge from this study as it relates to a particular epistemic population composing comparative education-that of CIES membership. However, since we are evaluating a subset, and not the entire world body of comparativists, any universalistic claims or generalizations about the entire field need to be made with caution and circumspection. While further work by, and responses from, other academics in the field are needed, we are confident that our findings are relevant to the larger ecosystem of comparative education.

The data show that the demographic composition of the CIES population is predominately North American with distinctive elements of heterogeneity. The field, as reflected by CIES, is composed of a membership whose disciplinary lenses, research interests, and academic training are highly disparate. 
TRENDS IN COMPARATIVE EDUCATION

TABLE 23

Top 10 Figures by Gender: Combined And Disaggregated Rankings

\begin{tabular}{|c|c|c|c|c|c|}
\hline \multirow[b]{3}{*}{ Figure } & \multirow{3}{*}{$\begin{array}{c}\text { Combined } \\
\text { Rank }\end{array}$} & \multicolumn{4}{|c|}{ Gender } \\
\hline & & \multicolumn{2}{|c|}{ Male } & \multicolumn{2}{|c|}{ Female } \\
\hline & & $N$ & Rank & $N$ & Rank \\
\hline Phillip Altbach & 1 & 48 & 1 & 34 & 1 \\
\hline Martin Carnoy & 2 & 38 & 2 & 27 & 2 \\
\hline Robert Arnove & 3 & 25 & 5 & 27 & 2 \\
\hline Harold Noah & 4 & 36 & 3 & 10 & 10 \\
\hline George Bereday & 5 & 30 & 4 & 12 & 8 \\
\hline Nelly Stromquist & 6 & 14 & 8 & 24 & 4 \\
\hline Paulo Freire & 7 & 19 & 6 & 17 & 5 \\
\hline Erwin Epstein & 8 & 19 & 6 & 12 & 8 \\
\hline Gail Kelly & 9 & 12 & 10 & 16 & 6 \\
\hline Ruth Hayhoe & 10 & 14 & 8 & 13 & 7 \\
\hline Responses & 447 & 255 & & 192 & \\
\hline
\end{tabular}

Note. - Chi-square value $=23.252(p<.01)$.

While broadly situated to study the forces shaping education around the world, the field of comparative education lends itself naturally to a multidisciplinary approach and is continually recasting itself as new partners enter the conversation. And, hence, its boundaries are much more flexible and pliant because of the larger epistemic contests facing other social sciences disciplines. It is also susceptible to a variety of calls for change because of the polyvocality inherent in its member composition and scholarly endeavors. Because of the Society's disciplinary eclecticism (see table 4 online, where 211 areas of primary emphasis were designated by the respondents) and open admission criteria, it appears to be a group with a relatively flexible professional identity and one that is also quite transient. With a relatively steep membership turnover within the past decade, as well as an age demo-

TABLE 24

Top 10 Universities by Gender: Combined and Disaggregated Rankings

\begin{tabular}{|c|c|c|c|c|c|}
\hline \multirow[b]{3}{*}{ University } & \multirow{3}{*}{$\begin{array}{c}\text { Combined } \\
\text { Rank }\end{array}$} & \multicolumn{4}{|c|}{ Gender } \\
\hline & & \multicolumn{2}{|c|}{ Male } & \multicolumn{2}{|c|}{ Female } \\
\hline & & $N$ & Rank & $N$ & Rank \\
\hline Stanford & 1 & 107 & 1 & 71 & 1 \\
\hline Columbia & 2 & 77 & 2 & 40 & 3 \\
\hline Harvard & 3 & 58 & 4 & 47 & 2 \\
\hline Chicago & 4 & 65 & 3 & 18 & 7 \\
\hline University of California, Los Angeles & 5 & 54 & 5 & 22 & 5 \\
\hline London & 6 & 47 & 6 & 18 & 7 \\
\hline Pittsburgh & 7 & 40 & 7 & 19 & 6 \\
\hline Ontario Institute for Studies in Education & 8 & 24 & 9 & 27 & 4 \\
\hline State University of New York—Buffalo & 9 & 33 & 8 & 11 & 9 \\
\hline Florida State University & 10 & 16 & 10 & 11 & 9 \\
\hline Responses & 805 & 521 & & 284 & \\
\hline
\end{tabular}

Note. - Chi-square value $=25.142(p<.01)$. 
COOK, HITE, AND EPSTEIN

TABLE 25

Top 10 Organizations by Gender: Combined and Disaggregated Rankings

\begin{tabular}{|c|c|c|c|c|c|}
\hline \multirow[b]{3}{*}{ Organization } & \multirow{3}{*}{$\begin{array}{l}\text { Combined } \\
\text { Rank }\end{array}$} & \multicolumn{4}{|c|}{ Gender } \\
\hline & & \multicolumn{2}{|c|}{ Male } & \multicolumn{2}{|c|}{ Female } \\
\hline & & $N$ & Rank & $N$ & Rank \\
\hline World Bank & 1 & 135 & 1 & 94 & 1 \\
\hline UNESCO & 2 & 109 & 2 & 75 & 2 \\
\hline U.S. Agency for International Development (USAID) & 3 & 52 & 3 & 38 & 3 \\
\hline UNICEF & 4 & 27 & 5 & 32 & 4 \\
\hline United Nations & 5 & 19 & 7 & 24 & 5 \\
\hline $\begin{array}{l}\text { Organization for Economic Cooperation and Devel- } \\
\text { opment (OECD) }\end{array}$ & 6 & 28 & 4 & 15 & 7 \\
\hline CIES & 7 & 24 & 6 & 9 & 9 \\
\hline Ford Foundation & 8 & 15 & 8 & 8 & 10 \\
\hline Academy for Educational Development (AED) & 9 & 6 & 10 & 15 & 6 \\
\hline International Monetary Fund (IMF) & 10 & 7 & 9 & 10 & 8 \\
\hline Responses & 739 & 422 & & 317 & \\
\hline
\end{tabular}

Note. - Chi-square value $=22.068(p<.01)$.

graphic that is conspicuously young (see tables 9 and 10 online), it possibly faces even greater challenges for boundary continuity, maintenance of cumulative gains in lines of inquiry, and a sustained sense of the field's historical development. These challenges are perhaps evidenced by data that indicate only weak agreement in the field regarding the most influential themes (see table 14), works (table 15), and figures (table 17). The fact that the vast majority of those figures and works are contemporary reveals a particular epistemological hegemony in and of itself and a weak sense by CIES members of the field's longer history. Shifts in outlook experienced in the field's history manifest the increased eclecticism of sources seen as relevant to comparative education as well as increased awareness of the interconnectedness of issues.

TABLE 26

Top 10 Works by Having Taught an Introductory Comparative Education Course: Combined and Disaggregated RANKings

\begin{tabular}{|c|c|c|c|c|c|}
\hline \multirow[b]{3}{*}{ Work } & \multirow{3}{*}{$\begin{array}{c}\text { Combined } \\
\text { Rank }\end{array}$} & \multicolumn{4}{|c|}{ Taught Introductory CIES } \\
\hline & & \multicolumn{2}{|c|}{ Yes } & \multicolumn{2}{|c|}{ No } \\
\hline & & $N$ & Rank & $N$ & Rank \\
\hline Freire $(1970)$ & 1 & 14 & 2 & 18 & 1 \\
\hline Noah and Eckstein (1969) & 2 & 21 & 1 & 5 & 6 \\
\hline Altbach and Kelly (1986) & 3 & 10 & 5 & 7 & 4 \\
\hline Altbach, Arnove, and Kelly (1982) & 4 & 10 & 5 & 7 & 4 \\
\hline Arnove and Torres (1999) & 5 & 6 & 9 & 10 & 3 \\
\hline Carnoy (1974) & 6 & 11 & 4 & 5 & 6 \\
\hline Comparative Education Review & 7 & 5 & 10 & 11 & 2 \\
\hline Bereday (1964) & 8 & 14 & 3 & 1 & 10 \\
\hline Kandel (1933) & 9 & 8 & 7 & 4 & 8 \\
\hline King (1958) & 10 & 8 & 7 & 2 & 9 \\
\hline Responses & 175 & 107 & & 70 & \\
\hline
\end{tabular}

Note. - Chi-square value $=26.53(p<.01)$. 
TRENDS IN COMPARATIVE EDUCATION

TABLE 27

Top 10 Figures by Having Taught an Introductory Comparative Education Course: Combined and Disaggregated Rankings

\begin{tabular}{|c|c|c|c|c|c|}
\hline \multirow[b]{3}{*}{ Figure } & \multirow{3}{*}{$\begin{array}{c}\text { Combined } \\
\text { Rank }\end{array}$} & \multicolumn{4}{|c|}{ Taught Introductory CIES } \\
\hline & & \multicolumn{2}{|c|}{ Yes } & \multicolumn{2}{|c|}{ No } \\
\hline & & $N$ & Rank & $N$ & Rank \\
\hline Phillip Altbach & 1 & 44 & 1 & 39 & 1 \\
\hline Martin Carnoy & 2 & 28 & 3 & 37 & 2 \\
\hline Robert Arnove & 3 & 20 & 5 & 32 & 3 \\
\hline Harold Noah & 4 & 31 & 2 & 16 & 9 \\
\hline George Bereday & 5 & 25 & 4 & 17 & 7 \\
\hline Nelly Stromquist & 6 & 10 & 9 & 28 & 4 \\
\hline Paulo Freire & 7 & 16 & 6 & 20 & 5 \\
\hline Erwin Epstein & 8 & 15 & 7 & 17 & 7 \\
\hline Gail Kelly & 9 & 13 & 8 & 15 & 10 \\
\hline Ruth Hayhoe & 10 & 9 & 10 & 18 & 6 \\
\hline Responses & 447 & 211 & & 239 & \\
\hline
\end{tabular}

Note. - Chi-square value $=21.206(p<.01)$

Because of its disparate nature, comparative education is also being defined by a degree of internal antagonism and suspicion of any trend that seeks uniformity and by boundaries that are continually challenged, stretched, and blurred. It might be depicted more precisely as a field of study determined by the diversity of its research and interpretive enterprises, rather than one that has any established or consensual agenda. Interior and exterior forces are at work in the field today, with some who draw the field's boundaries in a more constricted way and some who emphasize broader disciplinary crosspollination. As a field whose membership gives legitimacy to inclusionary discourses and to varied and diverse perspectives, its content boundaries are explicitly challenged, particularly by those seeking to define what counts as comparative education and what does not. However, if maintenance of disciplinary boundaries is considered with profound misgivings, and if criteria and standards of integrity for what can be considered comparative education have become suspect, then what, if any, are the demarcations of the field? Comparative education today represents those engaged in an ongoing discourse in full consciousness of their own diversity, but remaining largely amenable to others who might contribute to the conversation.

If comparative education then is a consequence of the political economy of knowledge production, such a perspective raises new challenges to the field: How can it maintain a sense of continuity within this dynamic of selfconsciousness and redefinition? How can a field that is incessantly re-creating itself appreciate and build upon collective advances and sustained lines of scholarship and inquiry? Are there any unifying trends, or does the wariness of institutional perspectives mean that reading lists and syllabi are recurrently turned over with each transient theoretical fad? If drawing boundaries is 
COOK, HITE, AND EPSTEIN

TABLE 28

Top 10 Universities by Having Taught an Introductory Comparative Education Course: Combined and Disaggregated Rankings

\begin{tabular}{|c|c|c|c|c|c|}
\hline \multirow[b]{3}{*}{ University } & \multirow{3}{*}{$\begin{array}{c}\text { Combined } \\
\text { Rank }\end{array}$} & \multicolumn{4}{|c|}{ Taught Introductory CIES } \\
\hline & & \multicolumn{2}{|c|}{ Yes } & \multicolumn{2}{|c|}{ No } \\
\hline & & $N$ & Rank & $N$ & Rank \\
\hline Stanford & 1 & 83 & 1 & 96 & 1 \\
\hline Columbia & 2 & 60 & 2 & 58 & 3 \\
\hline Harvard & 3 & 38 & 6 & 68 & 8 \\
\hline Chicago & 4 & 42 & 3 & 41 & 4 \\
\hline University of California, Los Angeles & 5 & 41 & 5 & 36 & 5 \\
\hline London & 6 & 42 & 3 & 24 & 2 \\
\hline Pittsburgh & 7 & 30 & 7 & 30 & 7 \\
\hline Ontario Institute for Studies in Education & 8 & 19 & 9 & 32 & 5 \\
\hline State University of New York-Buffalo & 9 & 21 & 8 & 24 & 2 \\
\hline Florida State University & 10 & 9 & 10 & 18 & 10 \\
\hline Responses & 805 & 385 & & 427 & \\
\hline
\end{tabular}

Note. - Chi-square value $=19.107(p<.02)$

exclusionary by definition, how does the field evaluate the relative merits of that which should be included?

Related to these issues is the question of how a field perpetuates itself epistemologically. Typically, if a field is to transmit its own body of knowledge, it must have certain unifying or common points of reference that engender a semblance of shared attachment and community. Additionally, the identity of a particular field relies implicitly on the ability of its constituency to articulate and convey that identity to others. Thus, critical to its own survival, a field's process of inducting its own membership must include, to some degree, a cohesive transmission of a particular and identifiable body of knowledge. Challenges of this nature in the field of comparative education are reflected in the present study. Common points of reference that characteristically unite other fields can generally be found in thematic content, historic tradition, or boundary continuity. Comparative education exhibits little or no consensual references or orientations. Those entrusted to transmit the field do it in widely disparate ways, both in subject matter and in method of approach. Within this fragmented characterization of comparative education, what does the future hold? Without specifying how the shifting boundaries of the field will evolve, comparative education exists within an environment that promotes speculation.

Despite its multifarious difficulties, the field exhibits continued vitality and growth. University programs and centers dealing with issues relating to comparative and international studies are growing worldwide. ${ }^{38}$ Membership activity and interest in professional organizations focused on comparative and

${ }^{38}$ See W. Loxley, "Comparative and International Education: Organizations and Institutions," in Husén and Postlethwaite, eds. (see n. 11 above), pp. 933-42. See also Altbach and Tan (n. 20 above). 
international education is multiplying. ${ }^{39}$ The field has grown from a small enclave of scholars primarily in North America and Europe before the Second World War to a worldwide contingent of scholars, teachers, policy makers, and students. While there have been robust and cumulative increases in theory and knowledge, the strength of the field is that it is woven of threads of many kinds of thinking. As such, the field seems to have a commitment to inclusion as a conversational and theoretical ideal. As many others have argued on behalf of other discourse frames, this is a good sign. The epistemic health of any particular field is often a function of its willingness to accommodate multiple voices, particularly of those who have traditionally been marginalized from the discussion. Mark Weinstein (among others) argues for inclusion as an ideal that should generally govern all metadiscourses: "Discourse frames . . . are to be judged for their adequacy in terms of their ability to include, without prejudice, all points of view within their scope. . . . The systematic exclusion of a point of view indicates a structural failing in the discourse frame." ${ }^{\prime 0}$

Thus, comparative education is a field that is alive and well, and will undoubtedly remain so for the coming century. All fields must have boundaries, however porous, or it would be impossible to differentiate them one from the other. As R. F. Arnove, P. G. Altbach, and G. P. Kelly remind us, while comparative education remains a "loosely bounded field," it is "held together by a fundamental belief that education can be improved and can serve to bring about change for the better in all nations." ${ }^{41}$ Increased globalization, along with value placed on inclusionary discourse, portend a future of continued diversity and change. As new voices enter the conversation, additional questions will inevitably emerge, informing and contouring the field even further. The shifts taking place in the nature of comparative education will be the prerogative of its own changing membership, because, after all, a field becomes what it is thought to be in the minds of its own participants. And because of the very nature of the field, this process will likely remain dynamic and vibrant, once again defying a simple definition. Perhaps it is neither possible nor desirable that such a definition be construed.

\footnotetext{
${ }^{39}$ Erwin H. Epstein, “Comparative Education Review Annual Report for 1992," report submitted to the CIES Board of Directors, 1993.

${ }^{40}$ Mark Weinstein, "Rationalist Hopes and Utopian Visions," Inquiry: Critical Thinking across the Disciplines 11, no. 3 (1993): 20. Many others argue for the causal efficacy of inclusion in achieving epistemic objectivity for a variety of disciplinary contexts; see Nicholas C. Burbules, Dialogue in Teaching: Theory and Practice (New York: Teachers College Press, 1993); Lorraine Code, "Taking Subjectivity into Account," in Feminist Epistemologies, ed. Linda Alcoff and Elizabeth Potter (New York: Routledge, 1993), pp. 15-48; Helen Longino, Science as Social Knowledge: Values and Objectivity in Scientific Inquiry (Princeton, N.J.: Princeton University Press, 1990); Sandra Harding, Whose Science? Whose Knowledge? Thinking from Women's Lives (Ithaca, N.Y.: Cornell University Press, 1991).

${ }^{41}$ R. F. Arnove, P. G. Altbach, and G. P. Kelly, eds. Emergent Issues in Education: Comparative Perspectives (Albany: SUNY Press, 1992), p. 1.
} 